\title{
Development of Educational Games as A Learning Media for Counseling Theory
}

\author{
Bambang Susanto $^{1}$, Rita Kumalasari ${ }^{2}$, Ismail ${ }^{3}$, Muhamad Arief Maulana ${ }^{4}$, Hamda \\ Kharisma $^{5}$ \\ \{bambang_susanto43@yahoo.com ${ }^{1}$, rita.kumalasari17@yahoo.com ${ }^{2}$, maulgonzales86@gmail.com $\left.{ }^{4}\right\}$ \\ Veteran Bangun Nusantara University, Indonesia ${ }^{12345}$
}

\begin{abstract}
This study aims at developing educational games that would assist college students to practically and effectively learn Counseling theory study program in Veteran Bangun Nusantara University of Sukoharjo. Due to the limited time, the researcher made use of the R \& D development method. The product, which has an average score of 37.00 and 36.00 is said to be categorized as "very good." A pre-trial test using 6 students gave an average score of 35 (medium category), while a post-test trial using came number resulted in 85 (high category). Based on the final field trials, it can be concluded that the development of educative games for counseling theories on the students are worthy to be used as a medium to improve and enhance the understanding of the counseling therories.
\end{abstract}

Keywords: Counseling theories, Games, Valid, Practical, Effective.

\section{Introduction}

Guiding is an educational activity that involves interaction between the instructor and students. The supervisor or teacher is known as the facilitator, and is also the main source of learning. However, despite the various teaching methods adopted by the facilitator, the right learningmaterial is yet to be achieved. Teaching activities comprises of the material, teaching techniques, students and objectives. Learning techniques are strongly influenced by the objectives and characteristics of the material

Theory is a foundation of thinking comprising of descriptive understanding, and empirical knowledge. It's inseparable from the history of development theory. Studying counseling theories is a foundation of thinking to carry out its practices. However understanding the concept by reading is less effective and saturating, making it difficult for students to understand and comprehend.

The teaching strategies adopted by lecturers were maximal, but the evaluation results showed that students still lacked understanding of the counseling theories. The disputed point was as a result of the use of poor teaching materials. From the results of observations and documentation carried out at the end of the first semester of 2015/2016. It was gathered that only about $30 \%$ of the total number of students understood the counseling theories. As a result of this, a new strategy is needed to ensure easy understanding, increase their individual interest, and ensure the practically understand the theories, as they are . the foundation of the mind of a counselor in carrying out guidance and counseling services. 


\section{Literature Review and Hypothesis}

Theory of guidance and counseling is built on the philosophical foundation of human nature. Counseling theory in the end must be a "personal theory" of counselors that reflects the integration between personal and professional aspects of ones need. Theory of guidance and counseling in [15], is defined as an education science references underlying personality development and changes in individual behavior. There are three models that underlie counseling theories namely relational, cognitive and behavioral models.

1. The Relational Model in guidance and counseling is an approach developed from client-centered therapy [18]

2. The Cognitive Model as defined by Sigmud Freud, using the psychoanalytic approach [5] is the main source for counseling and psychotherapy in affective cognitive models. It helps counselees develop new conceptual ideas about themselves and their situations.

3. The behavioral model rejects the world, personality traits and ego in individuals which are the main strengths of psychoanalytic theory, as it considers them unobservable.

4. The existence of guidance and counseling as evident from the results of the study by Sunaryo Kartadinata [12], describes it as a logical consequence of the nature of education itself. The guidance and counseling process is used to empower individuals through interaction.

Games are fun activities that one engages in for fun or amusement. According to Berlyne [19], a game is an exciting and fun activity which satisfies the urge to explore. Ismail [22], defines games as play activities carried out in order to seek pleasure and satisfaction, characterized by "win-lose".

The urge to explore through games involves curiosity and desire for information by digging and searching. It offers individuals the possibility of novelty, complexity, uncertainty, surprise and disharmony.

According to Greek Philosophy "in games there are always two main elements, eros (feeling happy, glad, cheerful) or fun and agon (struggle, enthusiasm) or struggle " [17]

Educational games according to Asfandiyar, games function to improve individual intelligence, stimulate various basic abilities, get diverse stimulation, train rigor, perseverance, and basic concepts, , stimulate creativity and train problem solving. Users, find themselves overwhelmed and indifferent to obtaining a sound theoretical foundation, and opt for more techniqueoriented practices. However, researchers who support technical eclecticism argue otherwise, asserting that a client's needs should determine a clinician's orientation [7]

The brain is not in opposition to the cognitive, emotional, behavioral attributes associated with interviewing and counseling. In fact, one of the clearest findings is that it needs environmental stimulation to grow and develop [11]. In research it is expected that educational games contain counseling theories that can stimulate the brain in students. 


\section{Reseach Methods}

The result of this study are the development of educational games as a practical and effective guidance media to enhance students' understanding of counseling theories. Research procedures include [6]: Model Design and Development which is traversed by (1) introduction, (2) planning, (3) hypothetical model development and review, (4) revision, and model development (5) limited trials, (6) revised test results, (7) broader trials, (8) revision of the final model, and (10) dissemination and socialization. Datasets from this research can be accessed from https://osf.io/hevq9/ [13] from

the Open Science Frameworks.

\section{Results and Discussions}

Analyzing student needs with respect to the counseling theories using 82 students found the following table :

Tabel 1.

\begin{tabular}{|c|c|c|c|c|c|c|c|}
\hline \multirow[b]{2}{*}{ No } & \multirow{2}{*}{$\begin{array}{l}\text { Material for counseling } \\
\text { theories }\end{array}$} & & \multicolumn{4}{|c|}{ Category } & \multirow[b]{2}{*}{ Total } \\
\hline & & & Low & Medium & High & $\begin{array}{l}\text { Very } \\
\text { High }\end{array}$ & \\
\hline \multirow[t]{2}{*}{1} & \multirow{2}{*}{$\begin{array}{l}\text { Character Name and basic } \\
\text { theory concept }\end{array}$} & $\mathrm{F}$ & 47 & 30 & 5 & 0 & 82 \\
\hline & & $\%$ & $57.31 \%$ & $36.59 \%$ & $6.10 \%$ & $0 \%$ & $100 \%$ \\
\hline \multirow[t]{2}{*}{2} & \multirow{2}{*}{$\begin{array}{l}\text { Assumption problematic } \\
\text { behavior }\end{array}$} & $\mathrm{F}$ & 56 & 18 & 8 & 0 & 82 \\
\hline & & $\%$ & $68.29 \%$ & $21.96 \%$ & $9.75 \%$ & $0 \%$ & $100 \%$ \\
\hline \multirow[t]{2}{*}{3} & \multirow[t]{2}{*}{ Purpose of Counseling } & $\mathrm{F}$ & 45 & 20 & 17 & 0 & 82 \\
\hline & & $\%$ & $54.87 \%$ & $24.40 \%$ & $20.73 \%$ & $0 \%$ & $100 \%$ \\
\hline \multirow[t]{2}{*}{4} & \multirow{2}{*}{$\begin{array}{l}\text { Description of the } \\
\text { counseling process }\end{array}$} & $\mathrm{F}$ & 65 & 8 & 7 & 0 & 82 \\
\hline & & $\%$ & $79,26 \%$ & $9.75 \%$ & $8.53 \%$ & $0 \%$ & $100 \%$ \\
\hline \multirow[t]{2}{*}{5} & \multirow{2}{*}{$\begin{array}{l}\text { Counseling techniques in } \\
\text { theory }\end{array}$} & $\mathrm{F}$ & 48 & 19 & 15 & 0 & 82 \\
\hline & & $\%$ & $58.53 \%$ & $23.17 \%$ & $18.30 \%$ & $0 \%$ & $100 \%$ \\
\hline \multirow[t]{2}{*}{6} & \multirow{2}{*}{$\begin{array}{l}\text { Evaluation counseling } \\
\text { theory approach }\end{array}$} & $\mathrm{F}$ & 38 & 32 & 12 & 0 & 82 \\
\hline & & $\%$ & $46.34 \%$ & $39.03 \%$ & $14.63 \%$ & $0 \%$ & $100 \%$ \\
\hline \multirow[t]{2}{*}{7} & \multirow{2}{*}{$\begin{array}{l}\text { Limitations of the } \\
\text { Approach }\end{array}$} & $\mathrm{F}$ & 51 & 28 & 3 & 0 & 82 \\
\hline & & $\%$ & $62.20 \%$ & $34.15 \%$ & $3.65 \%$ & $0 \%$ & $100 \%$ \\
\hline \multirow[t]{2}{*}{8} & \multirow[t]{2}{*}{ Service Strategy } & $\mathrm{F}$ & 39 & 26 & 17 & 0 & 82 \\
\hline & & $\%$ & $47.57 \%$ & $31.70 \%$ & $20.73 \%$ & $0 \%$ & $100 \%$ \\
\hline \multirow[t]{2}{*}{9} & \multirow{2}{*}{$\begin{array}{l}\text { Problems in understanding } \\
\text { counseling theories }\end{array}$} & $\mathrm{F}$ & 48 & 22 & 12 & 0 & 82 \\
\hline & & $\%$ & $58.53 \%$ & $26.82 \%$ & $14.63 \%$ & $6.09 \%$ & $100 \%$ \\
\hline
\end{tabular}

Educational game feasibility test results as a Guidance Media to enhance Understanding of the Counseling Theories are tested effectively. It is necessary to test the feasibility of the models rationally through expert judgment and practitioner assessment. The process of assessing rational theories of counseling is done by consulting counseling experts. Two experts were used in assessing the use of educational games for counseling theories. They 
were 1) Drs. Hadi Warsito, M.Sc, Kons an experienced UNESA lecturer with more than 30 years and an expert in the field of guidance and counseling, and Singgih Subiyantoro, M.Pd, a lecturer in the field of technology education expertise who has been teaching Education Technology program from 2015 to present and the game validator expert.

\section{Conclusion}

Counseling theories are very important for students, because they are the basis for counseling practice. Through the game theory application - counseling theory can give approval in the implementation of guidance to students guidance and counseling program. Game theory application - counseling theory has been validated by the experts from both media experts and material experts, as well as validation from the authorities. The results of the validation of this game with a high score can be used for one medium of guidance to understand counseling theories for students or prospective counselors.

\section{References}

[1] Arikunto, Suharsimi: Prosedur Penelitian Suatu pendekatan Praktek. Rineka Cipt,a Jakarta (2010)

[2] Arsyad, Azhar: Media Pembelajaran. Raja Grafindo Persada, Jakarta (2005)

[3] Azwar, Saifuddin: MetodePenelitian. PustakaPelajar,Yogyakarta (2012)

[4] Barbara, F.Y dan Hariastuti, R.T:Meningkatkan Partisipasi Siswa dalam Mengikuti Layanan Informasi Melalui Penggunaan Media Permainan. Jurnal Psikologi Pendidikan dan Bimbingan .http://ppb.unesa.ac.id. volume 12 no. 2 Desember 2011 (2011)

[5] Blocher, D.H: Developmental Counseling . $2^{\text {nd }}$ ed.New York: John Wiley \& Sons

[6] Borg and Gall : Educational Research. New York : Allyn and Bacon

[7] Cheston, S.E: New Paradigm for Teaching Counseling Theory and Practice. Conselor Education and Supervisi. Vol.39, p.254 - 269 (2000)

[8] Cottone, RR: Paradigm of Counseling and Psychoterapy, Revisited: Is Social Construcvism a Paradigm?.Journal of Mental Health.Vol 29, (3),p.189-203 (2007)

[9] Departemen Pendidikan Nasional: Penataan Pendidikan Profesional Konselor dan layanan Bimbingan dan Konseling dalam Jalur Pendidikan Formal.Jakarta (2007)

[10] Gibson,R.LdanMitchell,M.H: Bimbingan dan Konseling. Pustaka Pelajar, Yogyakarta (2011)

[11] Ivery, Allen, E.2011, Neuroscience and Counseling : Central Issue for Social Justice Leaders. Journal for Social Action in Counseling and Psychology.Vol.3 (1) .p.103 - 116 (2011)

[12] Kartadinata, S. Kerangka Kerja Bimbingan dan Konseling dalam Pendidikan: pendekatan ekologis sebagai suatu alternatif. Pidato Pengukuhan Jabatan Guru Besar. IKIP Bandung (1996)

[13] Kumalasari R and Sutanto B : Dataset of "Development Of Educational Games As A Learning Media For Counseling Theory” https://osf.io/hevq9/ (2019)

[14] Mayer,RE: Multimedia Learning, Prinsip-Prinsip dan Aplikasi. PustakaPelajar,Yogyakarta (2009)

[15] Natawidjaja dkk: Rujukan Filsafat, Teori dan Paksis Ilmu Pendidikan, Uversitas Pendidikan Indonesia Press, Bandung (2007)

[16] Nursalim, Mochamad and Mustaji: Media Bimbingan dan Konseling. Unesa University Press, Surabaya (2010)

[17] Rahmawati, N dan Mujib, F: Permainan Edukatif Pendukung Pembelajaran Bahasa Arab (2). Diva Press, Yogyakarta (2012)

[18] Rogers, C: Client Centered Therapy.Boston: Houghton-Mifflin

[19] Santrock, J.W. Perkembangan Masa Hidup (Life Span Devolepment) Jilid 1. (alih bahasa : Bebedictine widyasinta). Jakarta: Erlanga (2012) 
[20] Sugiyono: Metode Penelitian Pendidikan Pendekatan Kuantitatif, Kualitatif dan R\&D. Alfabeta, Bandung (2011)

[21] Suryabrata, Sumadi: Metodologi Penelitian. Raja GrafindoPersada, Jakarta (2011)

[22] Suwarjo and Eliasa, EI. 55 Permainan (Games) dalam Bimbingan dan Konseling. Paramitra publishing, Yogyakarta (2011)

[23] Wampold, Bruce, E.,\& Imel, Zac, E: The Great Psychotheraoy Debate:the evidence for what makes psychoterapy work (12nd edition), New York : Routledge (2015) 